\title{
Increased concentrations of tumour necrosis factor (TNF) and soluble TNF receptors in biliary obstruction in mice; soluble TNF receptors as prognostic factors for mortality
}

\author{
M H A Bemelmans, J W M Greve, D J Gouma, W A Buurman
}

\begin{abstract}
Systemic tumour necrosis factor (TNF) is present in jaundiced mice. Two soluble TNF receptors, sTNFr-P55 and sTNFr-P75 are reported to play a part in the natural defence against TNF. This study investigated the properties of circulating TNF and STNFr in jaundiced mice. The data show that TNF in these mice is biologically inactive and that an increase of both sTNFr is seen $(p<0.001)$. Surgical trauma in jaundiced mice is known to be accompanied by a high mortality (36\%) and increased TNF concentrations. This study shows that both systemic TNF and sTNFr concentrations are increased after surgical trauma in jaundiced mice and that sTNFr concentrations rather than TNF concentrations were found to be correlated with mortality. In line with this finding this study showed that lactulose pretreatment before a surgical trauma in these mice significantly reduces postoperative concentrations of sTNFrP75 $(p<0.005)$ and mortality $(0 \% ; p<0.05)$ without reducing TNF concentrations, while anti-TNF antibodies were ineffective. In conclusion, these data suggest that TNF in biliary obstruction is rapidly inactivated by increased concentrations of sTNFr. Furthermore, sTNFr concentrations rather than TNF concentrations show a good correlation with mortality after surgery in obstructive jaundice. The positive effect of lactulose on mortality could be caused by a decreased inflammatory status.

(Gut 1996;38: 447-453)
\end{abstract}

Department of Surgery, Faculty II, University of Limburg, Maastricht, the Netherlands M H A Bemelmans IW M Greve W A Buurman

Department of Surgery, Academical Medical Centre, Amsterdam, the Netherlands D J Gouma

Correspondence to: Dr M H A Bemelmans, Dr M H A Bemelmans, University of Limburg, Department of Surgery, Faculty II, PO Box 616, $6200 \mathrm{MD}$, Maastricht, the Netherlands.

Accepted for publication 28 September 1995
Keywords: cytokines, tumour necrosis factor (TNF), soluble TNF receptors (sTNFr), obstructive jaundice.

Endotoxaemia is reported to be present in biliary obstruction in humans as well as in animals. ${ }^{12}$ Moreover, tumour necrosis factor (TNF $\alpha$, unless stated otherwise), an indicator of an ongoing inflammatory process, is present in the circulation of biliary obstructed mice. ${ }^{3} \mathrm{It}$ was shown that surgery in biliary obstructed mice resulted in an increase in circulating TNF and in a high mortality. ${ }^{4}$ Various anti-TNF lactulose, an agent that reduces TNF release by macrophages in vitro, ${ }^{5}$ have been tested. Lactulose syrup given orally before operation was the only agent that reduced the mortality treatments such as an anti-TNF mAb and after surgery in these mice by a still unresolved mechanism, this in contrast with preoperative anti-TNF treatment. These data suggested that blocking circulating TNF, using antiTNF mAb, is not crucial in preventing the observed mortality. ${ }^{4}$ This is in contrast with the effect of anti-TNF mAbs in septic models where anti-TNF treatment was shown to be highly effective. ${ }^{6}$ The fact that systemic antiTNF treatment fails in the obstructive jaundice model, does not exclude an important role for TNF, as TNF concentrations at cellular level may be not sufficiently affected. Moreover, the fact that endotoxin, a strong inducer of TNF, plays an important part not only in obstructive jaundice ${ }^{7}$ but also in other diseases, ${ }^{89}$ supports the hypothesis that TNF is of major importance in the pathophysiology of these diseases.

More recently it has been reported that TNF can circulate in a bioactive form and an inactive form. ${ }^{10}$ The second form is immunologically detectable and probably consists of complexes of TNF bound to TNF binding proteins, which represent the most likely soluble TNF receptors (sTNFr). ${ }^{11}$ There are two TNFr, the $55 \mathrm{kDa}$ TNF receptor (TNFrP55) and the $75 \mathrm{kDa}$ receptor (TNFrP75). ${ }^{12-14}$ The extracellular parts of both TNFr are present as soluble TNF receptors (sTNFr) in the circulation and are released from the cell membrane in several inflammatory situations ${ }^{15-17}$ and experimental endotoxaemia in humans as well as in mice. ${ }^{16} 17$ On the one hand, liberation of TNFr from the cell surface can protect for the deleterious effects of TNF by binding circulating TNF and forming biologically inactive TNFsTNFr complexes, which are cleared by the kidney ${ }^{11}$ whereas on the other hand, the loss of cell surface receptors could lead to a transiently decreased responsiveness of cells to TNF. ${ }^{18}$ In those circumstances sTNFr could be regarded as TNF antagonists. Moreover, TNF-TNF receptor complexes have also been shown to behave as slow release reservoirs, ${ }^{18}$ which emphasises the biological importance of these complexes.

Endotoxin is a strong inducer of liberation of $\mathrm{sTNFr}^{17}$ and high sTNFr concentrations are considered to be an indicator for ongoing inflammatory response. However, also TNF increases concentrations of sTNFr, and sTNFr concentrations are considered to be important parameters for the status of inflammatory diseases. ${ }^{19} 20$ 
To investigate the inflammatory response in obstructive jaundice, we studied the role of TNF and sTNFr in obstructive jaundice. Moreover, as surgery in obstructive jaundice was associated with a high mortality and lactulose was shown to reduce lipopolysaccharide induced TNF release in vitro and to reduce endotoxaemia and survival in vivo, ${ }^{147}$ we investigated whether lactulose treatment (a powerful TNF inhibitor) affected sTNFr concentrations.

\section{Methods}

Animals

Female Swiss mice weighing $27 \cdot 5-34 \cdot 5$ grams, obtained from Charles River Breeding Laboratories (Heidelberg, Germany), were maintained on a standard laboratory diet and allowed free access to water. University of Limburg criteria for animal care and use of laboratory animals in research were followed throughout. The experiments were approved by the ethical committee for animal care of the University of Limburg.

\section{Reagents}

The reagents used were described previously, ${ }^{17}$ unless stated otherwise. TN3, a hamster monoclonal antibody specific for murine TNF was a generous gift from Celltech, Slough, England. ${ }^{21}$ Polyclonal rabbit antimurine TNF antiserum (RAMT) was produced by injecting rabbits with murine TNF kindly provided by Knoll/BASF (Ludwigshafen, Germany). Recombinant murine TNFr-P55, TNFr-P75, rabbit antisoluble murine TNFr-P55, and P75 were kindly provided by Dr D V Goeddel (Genentech, San Francisco, CA). Lactulose syrup (Duphalac) was a kind gift from Duphar (Weesp, the Netherlands). Crystalline lactulose (Legendal) was obtained from Inpharzam (Amersfoort, the Netherlands).

\section{Surgical procedures}

Female Swiss mice were operated on under light ether anaesthesia. Surgery was performed on a temperature controlled water mattress.

Bile duct ligation (BDL) - a long midabdominal incision was made and the common bile duct was ligated and divided following our modification of the method described by Pinto. ${ }^{322}$ After the BDL all mice received $1 \mathrm{ml}$ saline subcutaneously. Blood was sampled on defined time points. Mice were killed after 16 days.

Renal ischaemia was performed 14 days after BDL. On day 13, $100 \mu l$ of blood was taken from every mouse. The technique of renal ischaemia has been described earlier. ${ }^{4}$

\section{Experimental protocol}

$B D L$ - mice were randomised into two groups, a BDL group $(n=9)$ and a sham operated group ( $\mathrm{SH} ; \mathrm{n}=8)$. Blood was sampled the day before the operation and on day $4,8,12$, and day 16 . TNF was measured by enzyme linked immunosorbent assay (ELISA) and bioassay and sTNFr were measured by ELISA. Renal function was assessed by serum urea measurements and biliary obstruction was confirmed by bilirubin measurements. Renal blood flow measurements using para-aminohippuric acid were done in a separate group of mice.

Renal ischaemia - mice underwent a BDL or sham operation. BDL mice were randomised into four experimental groups: group 1, BDL mice receiving from day 11-14 twice daily $0.3 \mathrm{ml}$ distilled water orally (by gavage) followed by renal ischaemia at day 14 (BDL-renal ischaemia); group $2, \mathrm{BDL}$ mice receiving from day 11-14 twice daily $0.2 \mathrm{ml} 30 \%$ lactulose syrup orally followed by renal ischaemia at day 14 (BDL-Syr); group 3, BDL mice receiving from day 11-14 twice daily $0.2 \mathrm{ml}$ crystalline lactulose $(200 \mathrm{mg} / \mathrm{ml})$ orally followed by renal ischaemia at day 14 (BDL-Crys); group 4, BDL mice receiving $0.5 \mathrm{mg}$ of the monoclonal anti-TNF antibody (TN3) intraperitoneally dissolved in $0.5 \mathrm{ml}$ saline seven hours before the operation (BDL-TN3). The antibody was given seven hours before renal ischaemia because previous data in acute septic models showed a high efficacy when given at that time point. ${ }^{21} \mathrm{~A}$ control group of seven mice receiving $0.5 \mathrm{ml}$ saline intraperitoneally seven hours before the operation was used as a control group for group 4. However, because the results after renal ischaemia were not different from control group 1, which received fluid orally, these data are not shown.

The two different lactulose preparations were used as in vitro experiments showed that lactulose syrup is a more powerful TNF inhibitor than crystalline lactulose. ${ }^{5}$ Moreover, these data show that lactulose itself is not functional. Preliminary data show that the difference is possibly caused by differences in purification processes. The presence of 3-DGP, which is reported to be a biological anti-inflammatory agent, which is absent in crystalline lactulose could play a part in this phenomenon. ${ }^{23}$ Unfortunately, sufficient amounts of 3-DGP, necessary to further unravel this difference are lacking at this moment. Blood for TNF and sTNFr measurements was collected 90 minutes and 24 hours after renal ischaemia after which the mice were exsanguinated. During these 24 hours mortality was monitored. Animals with leakage of bile or animals that did not survive the first 90 minutes after reperfusion were excluded from the experiment. After correction for mortality during renal ischaemia, the remaining animals were divided as follows over the groups: group 1: $n=14$, group 2: $n=11$, group 3: $n=11$, group 4: $n=11$; sham operated group 5: $n=9$ (Table I).

\section{ELISA for murine TNF}

ELISA for murine TNF was performed as described earlier by Dentener. ${ }^{24}$ The ELISA has a lower detection limit of $50 \mathrm{pg} / \mathrm{ml}$ TNF. The ELISA recognises free TNF as well as 
TABLE I Experimental design

\begin{tabular}{|c|c|c|c|c|c|}
\hline & $\begin{array}{l}\text { Group 1 } \\
R I \\
(n=14)\end{array}$ & $\begin{array}{l}\text { Group } 2 \\
\text { Syr } \\
(n=11)\end{array}$ & $\begin{array}{l}\text { Group } 3 \\
\text { Crys } \\
(n=11)\end{array}$ & $\begin{array}{l}\text { Group } 4 \\
\text { TN3 } \\
(n=11)\end{array}$ & $\begin{array}{l}\text { Group } 5 \\
\text { Sham-RI } \\
(n=9)\end{array}$ \\
\hline Day 0 & BDL & $\mathrm{BDL}$ & BDL & BDL & Sham BDL \\
\hline Day 11 & PBS & Syr & Crys & - & PBS \\
\hline Day 12 & PBS & Syr & Crys & - & PBS \\
\hline Day 13 & PBS & Syr & Crys & - & PBS \\
\hline Day 14 & RI & RI & RI & TN3-RI & RI \\
\hline
\end{tabular}

$\mathrm{BDL}=$ bile duct ligation, $\mathrm{RI}=$ renal ischaemia, $\mathrm{TN} 3=$ monoclonal anti-TNF antibody, Crys $=$ crystalline lactulose, $\mathrm{Syr}=$ lactulose syrup. Serum TNF and sTNFr were measured by ELISA 90 minutes after reperfusion. Survival was assessed during 24 hours.

TNF bound to binding proteins (immunologically detectable TNF).

WEHI 164 cytotoxicity bioassay

Biological TNF activity was measured using the murine fibrosarcoma WEHI 164 cell line. ${ }^{25} 26$ The MTT method was used to assess cell killing as described previously. ${ }^{27} \mathrm{LD}_{50}$ ranged between 10 and $40 \mathrm{pg} / \mathrm{ml}$.

ELISA for soluble murine TNFr

ELISA for murine sTNFr was performed as described earlier. ${ }^{17}$ The detection limit for murine sTNFr-P55 is $5 \mathrm{pg} / \mathrm{ml}$ and for murine sTNFr-P75 $50 \mathrm{pg} / \mathrm{ml}$.

\section{Renal blood flow measurements}

Renal blood flow was assessed by modification of the method of Selkurt et al. ${ }^{28}$ Instead of administration of para-aminohippuric acid (PAH) by catheters we administered PAH by means of osmotic minipumps implanted intraperitoneally. To this end, six BDL operations and four sham operations were performed. Fourteen days after surgery, Osmotic Alzet minipumps (model 1003D, Alza Corporation, Palo Alto, CA) were implanted intraperitoneally. Before surgery, the pumps were filled with $100 \mu \mathrm{l}$ of $2 \cdot 1 \mathrm{M}$ PAH. After filling, they were incubated for four hours at $37^{\circ} \mathrm{C}$ in sterile saline to obtain stable flow. Thereafter, the pumps were implanted intraperitoneally. Blood was sampled 18,28 , and 52 hours after implantation. Blood was taken by orbital puncture and collected on ice in heparinised cups (Microvette CB1000, Sarstedt, Numbrecht, Germany). PAH was measured by standard techniques as described previously. ${ }^{29} \mathrm{PAH}$ extraction rate is considered to be more than $90 \%{ }^{30}$ Therefore, renal blood flow was calculated as input divided by the whole blood concentration of $\mathrm{PAH}$ in $\mathrm{ml} / \mathrm{min} .{ }^{30}$

\section{Statistical analysis}

Statistics were performed using the SPSS/PC+ Statistical Software Package. ${ }^{31}$ Differences in serum TNF and sTNFr concentrations were calculated using analysis of variance. Differences between TNF or sTNFr concentrations preoperatively or postoperatively and mortality were determined using the KruskalWallis test. Differences in mortality were calculated by the log rank test. Data are
TABLE II Renal blood flow ( $\mathrm{ml} / \mathrm{min}$ ) after bile duct ligation $(B D L)$ or sham operation

\begin{tabular}{llll}
\hline & 18 Hours $^{\star}$ & 28 Hours & 52 Hours \\
\hline Sham $(\mathrm{n}=4)$ & $2.55(0 \cdot 18) \dagger$ & $3.41(0 \cdot 85)$ & $2 \cdot 25(0 \cdot 51)$ \\
BDL $(\mathrm{n}=6)$ & $1.37(0.31)$ & $1.85(0 \cdot 49)$ & $2 \cdot 30(0 \cdot 24)$ \\
\hline
\end{tabular}

*Time point after implantation of osmotic minipump. Data are expressed as means (SEM).

expressed as means (SEM) unless stated otherwise. Probability values below 0.05 were considered to be statistically significant.

\section{Results}

Confirmation of jaundice and evaluation of renal function

Bilirubin concentrations in biliary obstructed mice, taken 16 days after the BDL were significantly higher compared with the sham operated control mice (277 (82) $\mu \mathrm{mol} / 1$ v $3 \cdot 7$ $(0 \cdot 8) \mu \mathrm{mol} / 1$, respectively; $\mathrm{p}<0.001)$, showing that the operation had been successful. Because biliary obstruction has been suggested to be accompanied by a changed renal function $^{32-34}$ and because TNF and sTNFr concentrations are affected by decreased renal function, ${ }^{11}$ we studied urea concentrations as well as renal blood flow. Urea measurements 16 days after BDL showed no significant differences between the BDL $(n=9)$ and the sham $(\mathrm{n}=8)$ mice $(8.3(5.4)$ v $9 \cdot 1 \quad(1.3)$ $\mathrm{mmol} / \mathrm{l}$; NS).

The implantation of the osmotic minipump in BDL mice for renal blood flow measurement resulted in a reduced renal blood flow 18 hours after implantation compared with control mice (Table II). The data show that the renal blood flow in BDL mice is only transiently reduced and the results suggest that this reduction is most probably caused by surgery. After surgery, the renal blood flow gradually improves resulting in comparable renal blood flow after 52 hours between BDL and control mice. The results of the urea concentrations and the renal blood flow data in BDL mice suggest that renal function is not or negligibly affected in BDL mice.

\section{Circulating TNF and kinetics of sTNFr after} $B D L$

Circulating TNF concentrations measured by ELISA before operation were below detection limit. After sham BDL operation, TNF concentrations remained undetectable during the experimental procedure. In the BDL group, however, there was a clear increase in circulating TNF that became evident after eight days, reaching peak concentrations after 16 days of $1.6 \mathrm{ng} / \mathrm{ml}(\mathrm{p}<0.001$; data not shown). Biologically active TNF could not be detected by the WEHI-bioassay in any of the samples, suggesting that TNF circulates as biologically inactive TNF-sTNFr complexes.

Whereas TNF is not detectable in serum of normal non-treated mice, we detected approximately $90 \mathrm{pg} / \mathrm{ml}$ sTNFr-P55 and $5 \cdot 5$ $\mathrm{ng} / \mathrm{ml}$ sTNFr-P75 in normal control mice, 

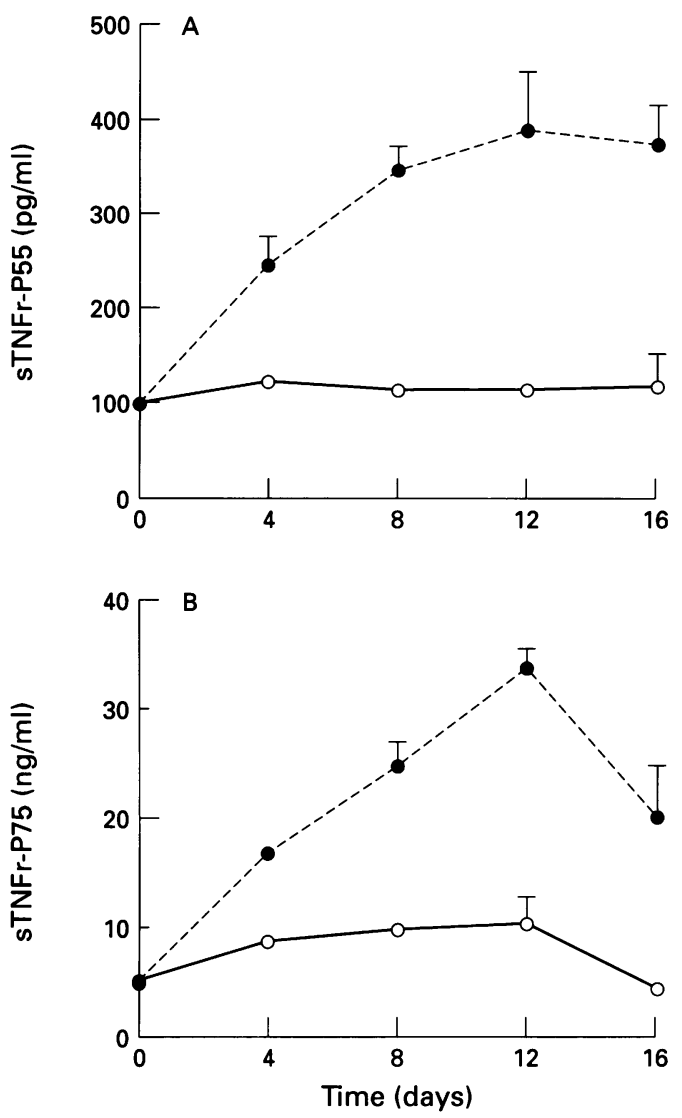

Figure 1: Serum sTNFr concentrations in BDL and sham operated mice. BDL mice are represented by closed circles $(n=9)$ and sham operated mice by open circles $(n=8)$. Serum sTNFr were monitored during 16 days.

(A) Represents sTNFr-P55 concentrations and

(B) represents $s T N F r-P 75$ concentrations. Data are expressed as means (SEM).

concentrations that are in the same range as we reported previously. ${ }^{17}$ Sham BDL operation resulted in a negligible increase in sTNFr-P75 concentrations, whereas sTNFr-P55 concentrations remained similar. Biliary obstruction, however, resulted in a

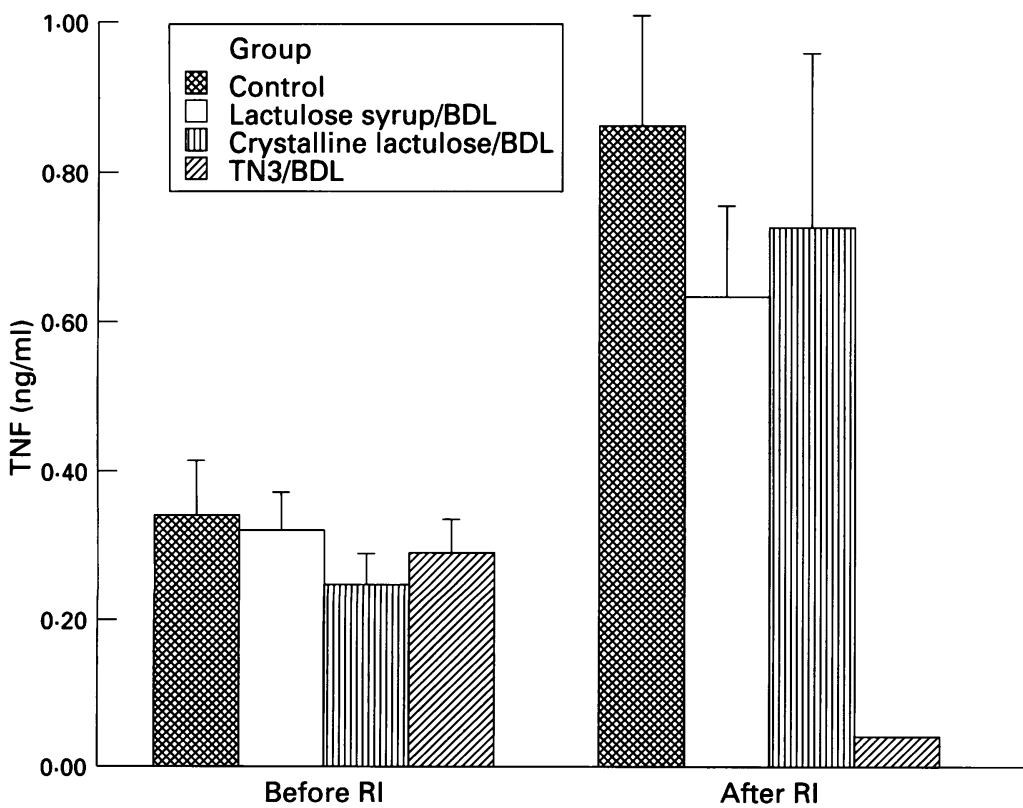

Figure 2: Serum TNF concentrations before and 90 minutes after renal ischaemia (RI) in $B D L$ mice. Control mice (group 1) $(n=14)$, lactulose syrup (group 2) treated BDL mice $(n=11)$, crystalline lactulose (group 3) treated $B D L$ mice $(n=11)$, and TN3 treated (group 4) BDL mice $(n=11)$, as measured by ELISA. Data are expressed as means (SEM). rapid increase in both sTNFr-P55 concentrations and sTNFr-P75 concentrations. sTNFr-P55 concentrations showed peak concentrations of $400 \mathrm{pg} / \mathrm{ml}$ after 12-16 days $(\mathrm{p}<0.01$ compared with sham operated controls; Fig 1A), while sTNFr-P75 concentrations showed peak concentrations after 12 days of $34 \mathrm{ng} / \mathrm{ml}(\mathrm{p}<0.01$ compared with the sham operated controls; Fig 1B). These increased concentrations are strongly suggestive of an ongoing inflammatory process in these mice. In a previous study it was shown that endotoxin administration ( $7 \cdot 5$ or $15 \mu \mathrm{g}$ per gram body weight) in combination with renal ischaemia in rats resulted in high TNF concentrations and high mortality, while either treatment separately was tolerated well in normal rats. ${ }^{35}$ In accordance with this study, renal ischaemia in jaundiced mice, a situation that is known to be accompanied by endotoxaemia results in a high mortality. ${ }^{4}$ Because endotoxaemia is associated with high TNF and sTNFr concentrations and as these concentrations are related to mortality, 8936 renal ischaemia was used as a surgical trauma model in BDL mice.

\section{Serum TNF and serum sTNFr after renal ischaemia}

TNF concentrations as determined by ELISA were below detection limit in the sham operated group and showed a small increase up to $0.21 \mathrm{ng} / \mathrm{ml}$ after renal ischaemia (data not shown). In the four experimental BDL groups, there were preoperatively no significant differences in serum TNF concentrations as measured by ELISA (Fig 2). Serum samples taken 90 minutes after renal ischaemia showed that serum TNF concentrations were significantly increased in group 1 (BDL-renal ischaemia group). As expected, TNF concentrations were significantly reduced in group 4 (anti-TNF group) compared with group 1, while they were not statistically different in group 2 (lactulose syrup group) and 3 (crystalline lactulose group) compared with group 1 (Fig 2). Moreover, no significant differences were seen between serum TNF concentrations of BDL mice before renal ischaemia from groups 1-4 that subsequently died compared with TNF concentrations of survivors $(p=0.91)$, nor was this difference present 90 minutes after renal ischaemia $(p=0.54)$. In none of the animals was the TNF as detected by ELISA biologically active after renal ischaemia (data not shown).

In the four individual treatment groups (groups 1-4), sTNFr-P55 concentrations and STNFr-P75 concentrations were similarly increased preoperatively before renal ischaemia (Fig $3 \mathrm{~A}$ and $\mathrm{B}$ ), while sTNFr concentrations in the sham group (group 5) were at the same level as normal control mice. After renal ischaemia, a significant increase was seen in sTNFr-P55 concentrations and sTNFr-P75 concentrations in all experimental groups, although the increase in the sham group subjected to renal ischaemia was much smaller compared with the BDL-renal ischaemia group 

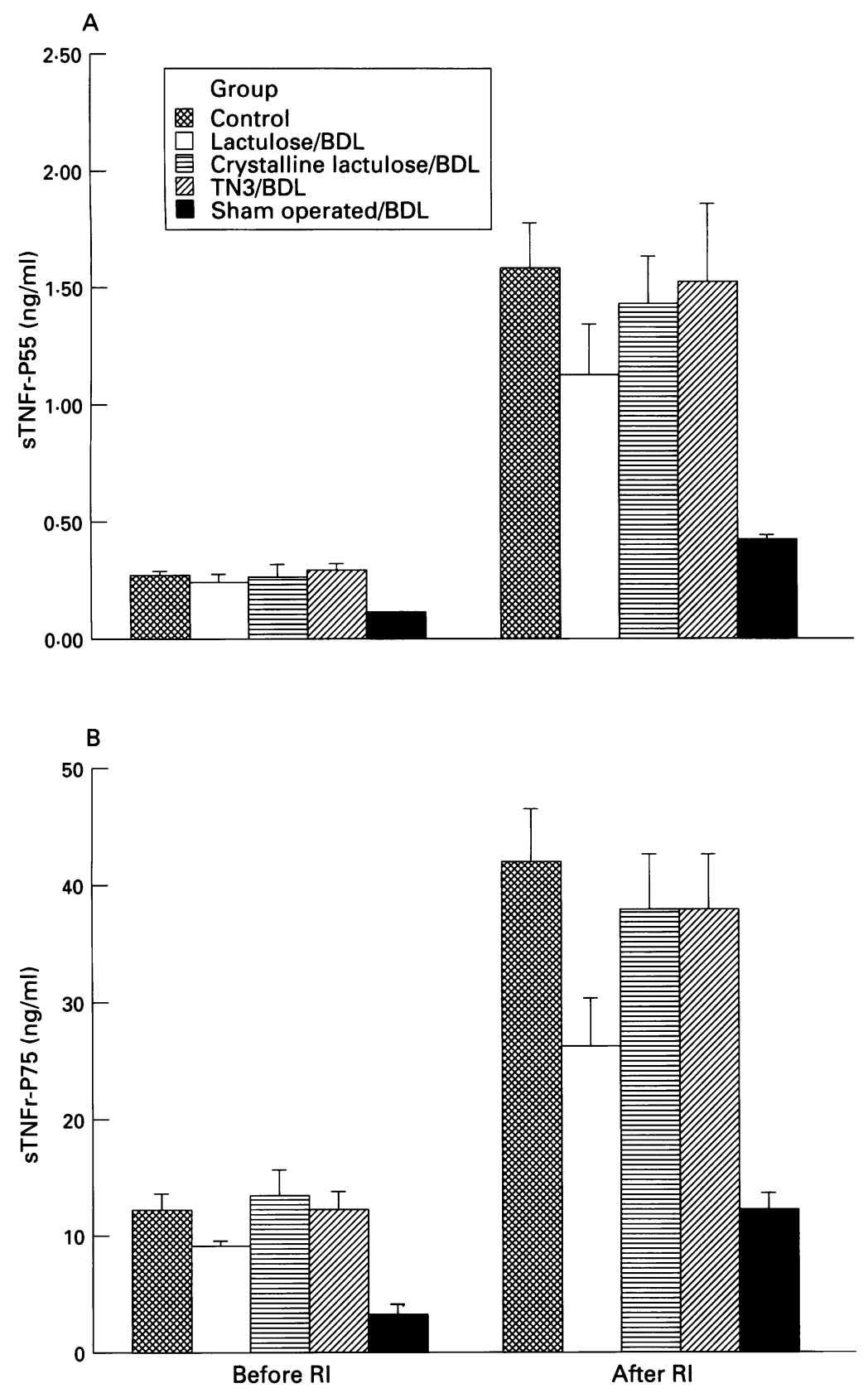

Figure 3: Serum sTNFr concentrations before and 90 minutes after renal ischaemia (RI) in BDL mice. Control mice (group 1) $(n=14)$, lactulose syrup (group 2) treated BDL mice $(n=11)$, crystalline lactulose (group 3) treated $B D L$ mice $(n=11), T N 3$ treated (group 4) $B D L$ mice $(n=11)$, and sham operated $B D L$ mice $(n=9)$. (A) Represents $s T N F r-P 55$ concentrations, $(B)$ represents $s T N F r-P 75$ concentrations. Data are expressed as means (SEM).
Mortality

Mortality in the BDL-renal ischaemia group was $36 \%$ (Table III). Pretreatment with TN3 or crystalline lactulose did not reduce mortality (both $45 \%$ ). However, in agreement with previous published data, lactulose syrup significantly reduced mortality $(0 \% ; \mathrm{p}<0.05)$. Preoperatively, there was a significant difference between both sTNFr-P55 and sTNFrP75 concentrations in mice of group 1-4 that survived renal ischaemia compared with the mice of those groups that did not survive renal ischaemia $(\mathrm{p}=0.035$ and $\mathrm{p}<0.005$, respectively). This difference was also present 90 minutes after renal ischaemia $(p<0.001$ and $\mathrm{p}<0 \cdot 001$, respectively; Fig 4).

\section{Discussion}

The presence of the cytokine TNF in the circulation is considered to be indicative of the presence of an ongoing inflammatory response. ${ }^{37}$ Increased concentrations of circulating sTNFr, which are considered to be antagonists of TNF, are also seen in the circulation during inflammation. ${ }^{19} 20$ During experimental endotoxaemia, sTNFr concentrations are strongly increased and remain, in contrast with systemic TNF, increased for a longer period of time. ${ }^{161720}$ The concentrations of sTNFr therefore can be considered, at least in part, as a consequence of TNF release. In previous studies, ${ }^{11} 38$ we obtained substantial evidence that the half life of these complexes is indeed longer than the half life of TNF alone and that the renal function is important in the clearance of these complexes. Therefore, sTNFr concentrations seem to be of value for monitoring the inflammatory response.

As obstructive jaundice is associated with endotoxaemia, we also determined sTNFr as well as TNF in BDL mice. The data showed that in BDL mice both TNF and sTNFr concentrations (sTNFr-P55 as well as sTNFrP75) are considerably increased, indicating an ongoing inflammatory process. These findings support previous data from our group showing the presence of systemic TNF and interleukin 6 , indicative for an inflammatory process in BDL mice. ${ }^{3}$

The presence of the detected TNF (bioactive and immunoreactive TNF) in BDL mice probably points to the presence of an ongoing synthesis of TNF after which the protein is rapidly inactivated in the circulation. ${ }^{10}$ We hypothesise that this inactivation is, at least partially, caused by formation of bio-inactive, immunologically detectable complexes of TNF with sTNFr. Indeed, we observed increased concentrations of both sTNFr in

TABLE III Mortality after renal ischaemia (RI)

\begin{tabular}{lcl}
\hline & Mortality (\%) & $p$ Value \\
\hline BDL/RI (5/14) & 36 & NA \\
TN3/RI (5/11) & 45 & NS \\
Lactulose syrup/RI (0/11) & 0 & $\mathrm{p}<0 \cdot 05$ \\
Crystalline lactulose/RI (5/11) & 45 & $\mathrm{NS}$ \\
Sham BDL/RI (0/9) & 0 & $\mathrm{p}<0.05$ \\
\hline
\end{tabular}

^Mortality was recorded during 24 hours. Abbreviations as in Table I. NA= not applicable. lactulose, in contrast with lactulose syrup, does not lead to low sTNFr concentrations seems to be in agreement with in vitro results where the first of these is less potent in reducing lipopolysaccharide induced TNF release by monocytes than the second, although in vivo TNF reduction is minimal.

(Fig $3 \mathrm{~A}$ and $\mathrm{B}$ ). There were no differences BDL-renal ischaemia mice (group 1) and the incr schaemia group, the crystalline lactulose group, TN3 group were not significantly different from each other, sTNFr-P75 concentrations were significantly reduced in the lactulose 

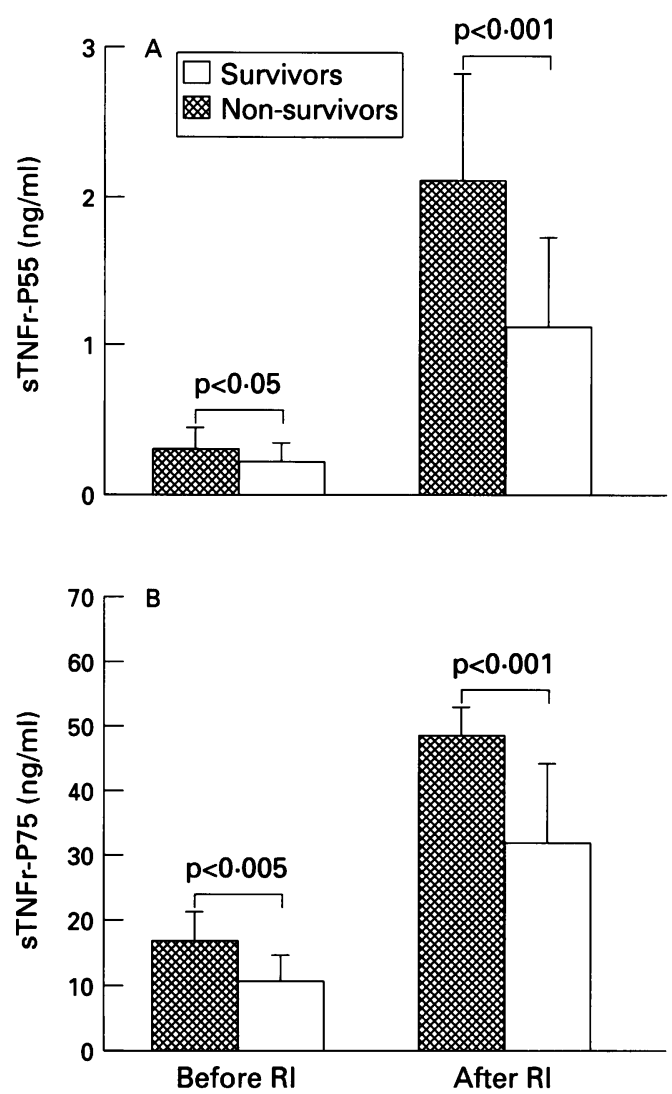

Figure 4: Serum sTNFr concentrations before and 90 minutes after renal ischaemia (RI) in all experimental $B D L$ mice (sham operated BDL mice excluded) in survivors ( $n=32)$ and non-survivors $(n=15)$. (A) Represents sTNFr-P55 concentrations, (B) represents sTNFr-P75 concentrations. Data are expressed as means (STD).

the circulation of BDL mice. Nevertheless, while TNF concentrations increased during the progression of obstructive jaundice, sTNFr concentrations reached plateau concentrations and sTNFr-P75 decreased after several days. Because bioactive TNF remained absent, these data suggest that even the diminished amount of sTNFr is capable of inactivating TNF. However, it is not certain whether sTNFr are the only inhibitors of TNF.

As TNF-sTNFr complexes are cleared by the kidney, ${ }^{11}$ it was essential to rule out that the observed increase in sTNFr after BDL resulted from diminished renal function. We therefore determined renal function by measuring serum urea and renal blood flow by $\mathrm{PAH}$ clearance in BDL mice. In contrast with several reports that describe a decreased renal function after biliary obstruction, ${ }^{32-34}$ but in agreement with others, ${ }^{39}$ we found no significant differences in renal function in BDL mice that could be held responsible for the massive increase in concentrations of circulating sTNFr. We conclude therefore that the increased concentrations of STNFr after BDL reflect an ongoing inflammatory process rather than a decreased renal function. The data regarding the renal blood flow show, however, that surgery in BDL mice (implantation of the pumps) is associated with a temporary reduction in renal blood flow. This seems to reflect the higher susceptibility of BDL mice to trauma.
In contrast with others who use also shorter periods of obstructive jaundice, ${ }^{40-42}$ our experiments use a biliary obstruction model of 14-16 days. It is known that mortality and morbidity after surgery in obstructive jaundice are significantly higher in high bilirubin groups. ${ }^{33} 43$ A previous study from our group, showed that maximal bilirubin concentrations were reached between $10-16$ days. $^{3}$ In addition, from day 12 after obstructive jaundice onwards significantly increased concentrations of interleukin 6 were seen in the circulation, pointing to an ongoing inflammatory process. Moreover, more severe haemodynamic changes and more pronounced decreases in reticuloendothelial function have been described after a longer period of obstructive jaundice. ${ }^{40-42}$

Intervention with lactulose syrup was the only treatment that resulted in a significantly reduced mortality while systemic TNF concentrations were not significantly reduced. This is in agreement with previous data that showed that TNF was of little prognostic importance for mortality. ${ }^{44}$ In contrast, sTNFr concentrations were found to be strongly correlated with mortality after surgery in jaundiced mice. The fact that the mice die despite high sTNFr concentrations, which are considered protective, could be because the amount of sTNFr is not sufficient to block all TNF effects, especially the effects in local tissue. Moreover, according to Aderka et al, these TNF-sTNFr complexes are potentially hazardous because they could function as slow release reservoirs. ${ }^{18}$

The protective mechanism of lactulose syrup is thus far unclear. The significant reduction in sTNFr-P75 concentrations suggest that the effect of lactulose syrup on mortality is the result of reduction of the inflammatory status of the mice. Lactulose syrup could reduce the inflammatory status by its reported reduction of endotoxaemia by inactivating endotoxins originating from the gut. ${ }^{1}$ However, a direct effect of lactulose on cytokine production by mononuclear phagocytes could also be responsible. ${ }^{5}$ The fact that crystalline lactulose is not as effective as lactulose syrup is in agreement with previous data showing that lactulose syrup is a more potent lipopolysaccharide inactivator ${ }^{1}$ and reduced more effectively TNF production of mononuclear phagocytes after lipopolysaccharide stimulation. ${ }^{5}$ The difference in effect between lactulose syrup and crystalline lactulose is expected to result from differences in purification process of both lactulose preparations. The putative presence of 3-deoxy-D-glyceropentulose (a compound that is known for its antiproliferative and cytotoxic properties) could play a part in the observed differences. ${ }^{23}$ In pilot experiments with different lactulose contaminants, 3-DGP seemed to inhibit TNF release after injection of endotoxin in mice (data not shown).

As already mentioned, increased concentrations of sTNFr are not only a result of an inflammatory response but are also influenced by renal function. ${ }^{3645}$ Recently, we found that 
plasma concentrations of both sTNFr are affected to an identical extent by decreased renal function (data not shown). After renal ischaemia, lactulose syrup affected only sTNFr-P75 concentrations, but not sTNFrP55 concentrations. Because of the discrepancy between both sTNFr concentrations, it is concluded that the reduction of sTNFr-P75 concentrations after renal ischaemia was more likely to be the result of the reduced inflammatory status rather than decreased clearance of the sTNFr by the kidneys. We cannot exclude, however, that the increased sTNFr concentrations after renal ischaemia are partially caused by diminished renal function.

In conclusion, the presence of TNF in inactivated form together with increased concentrations of both STNFr in the circulation of mice with biliary obstruction is indicative for an ongoing inflammatory process. Furthermore, the data show that sTNFr concentrations, in contrast with systemic TNF concentrations, correlate with mortality after a surgical trauma in jaundiced mice. Lactulose syrup treatment is associated with a positive effect on mortality and with a reduction of sTNFr-P75 concentrations, which suggests that the inflammatory response is reduced, although the underlying mechanism remains unclear. The clinical importance of increased sTNFr concentrations as an indicator for inflammation after surgery in obstructive jaundice remains to be elucidated.

We would like to thank Dr N E P Deutz for excellent advice and $\mathrm{M} v \mathrm{~d}$ Ven for assistance in experiments.

1 Pain JA, Bailey ME. Experimental and clinical study of lactulose in obstructive jaundice. Br $\mathcal{F}$ Surg 1986; 73: lactulose

2 Van Bossuyt H, Desmaretz C, Gaeta GB, Wisse E. The role of bile acids in the development of endotoxemia during
obstructive jaundice in the rat. F Hepatol 1990; 10: 274-9.

3 Bemelmans MHA, Greve JW, Gouma DJ, Buurman WA. Cytokines tumor necrosis factor and interleukin-6 in experimental biliary obstruction in mice. Hepatology 1992; 15: 1132-6.

4 Bemelmans MHA, Gouma DJ, Greve JW, Buurman WA. The effect of anti-TNF treatment on circulating tumor necrosis factor and mortality after surgery in jaundiced mice. Br F Surg 1993; 80: 1055-8.

5 Greve JW, Gouma DJ, van Leeuwen PAM, Buurman WA. Lactulose inhibits endotoxin induced tumour necrosis factor production by monocytes. An in vitro study. Gut 1990; 31: 198-203.

6 Beutler B, Milsark IW, Cerami AC. Passive immunization against cachectin/tumor necrosis factor protects mice from lethal effect of endotoxin. Science 1985; 229: 869-71.

7 Greve JW, Maessen JG, Tiebosch T, Buurman WA, Gouma DJ. Prevention of postoperative complications in jaundiced rats. Ann Surg 1991; 212: 221-7.

8 Millar AB, Singer M, Meager A, Foley NM, Johnson NMcI, Rook GAW. Tumour necrosis factor in bronchopulmonary secretions of patients with adult respiratory distress syndroms. Lancet 1989; ii: 712-4.

9 Waage A, Halstensen A, Espevik T. Association between tumour necrosis factor in serum and fatal outcome in patients with meningococcal disease. Lancet 1987; i: patients

10 Munck-Petersen C, Møller BK. Immunological reactivity and bioactivity of tumour necrosis factor. Lancet 1988; i: and bioact

11 Bemelmans MHA, Gouma DJ, Buurman WA. Influence of nephrectomy on tumor necrosis factor (TNF) clearance in a murine model. F Immunol 1993; 150: 2007-17.

12 Engelmann H, Holtmann H, Brakebush C, Avni ÝS, Sarov I, Nophar Y, et al. Antibodies to a soluble form of a tumor necrosis factor (TNF) receptor have TNF-like activity. f Biol Chem 1990; 265: 14497-504.

13 Engelmann $H$, Novick D, Wallach $D$. Two tumor necrosis factor-binding proteins purified from human urine: evidence for immunological cross-reactivity with cell surface tumor necrosis factor receptors. $\mathcal{f}$ Biol Chem 1990 265: 1531-6.

14 Brockhaus M, Schoenfeld HJ, Schlaeger EJ, Hunziker W, Lesslauer W, Loetscher H. Identification of two types of tumor necrosis factor receptors on human cell lines by monoclonal antibodies. Proc Natl Acad Sci USA 1990; 87: 3127-31.

15 Peetre C, Thysell H, Grubb A, Olsson I. A tumor necrosis factor binding protein is present in human biological fluids. Eur 7 Haematol 1988; 41: 414-9.

16 Spinas GA, Keller U, Brockhaus M. Release of soluble receptors for tumor necrosis factor (TNF) in relation to circulating TNF during experimental endotoxemia. $\mathcal{F}$ Clin Invest 1992; 90: 533-6.

17 Bemelmans MHA, Gouma DJ, Buurman WA. LPS induced sTNFr-receptor release in vivo in a murine model: investigation of the role of TNF, IL-1, LIF and IFN $\gamma$. F Immunol 1993; 151: 5554-62.

18 Aderka D, Engelmann H, Maor Y, Brakebush C, Wallach D. Stabilization of the bioactivity of tumor necrosis factor by its soluble receptors. $\mathcal{F}$ Exp Med 1992; 175: 323-9.

19 Cope AP, Aderka D, Doherty M, Engelmann H, Gibbons $\mathrm{D}$, Jones AC, et al. Increased levels of soluble tumor necrosis factor receptors in the sera and synovial fluid of patients with rheumatic diseases. Arthritis Rheum 1992; 35: $1160-9$

20 Van Zee KJ, Kohno T, Fischer E, Rock CS, Moldawer LL, Lowry SF. Tumor necrosis factor soluble receptors circulate during experimental and clinical inflammation and can protect against excessive tumor necrosis factor $\alpha$ in vitro and in vivo. Proc Natl Acad Sci 1992; 89: 4845-9.

21 Sheehan KCF, Ruddle NH, Schreiber RD. Generation and characterisation of hamster monoclonal antibodies that neutralizes murine tumor necrosis factors. $\mathcal{F}$ Immunol 1989; 142: 3884-93.

22 Pinto M, Kaplun A. Immune status in mice with experimental biliary obstruction. Clin Immunol Immunopathol 1980; 16: 396-405.

23 Derwent Publications Ltd. 1991: Europaische Patentanmeldung, Veröffentlichungsnummer: 0432309A1 Anmeldungsnummer: 89123301.7

24 Dentener MA, Greve JW, Maessen JW, Buurman WA. Role of tumor necrosis factor in the phenomenon of the enhanced sensitivity of animals to endotoxin after exposure to lead. Immunopharmacol Immunotoxicol 1989; 11: $321-4$.

25 Rollinghoff $M$, Warner NL. Specificity of in vivo tumor rejection assessed by mixing immune spleen cells with target and unrelated tumor cells. Proc Soc Exp Biol Med 1973; 144: 813-8.

26 Espevik T, Nissen-Meyer J. A highly sensitive cell line, WEHI 164 clone 13 , for measuring cytotoxic factor/tumor WEHI 164 clone 13 , for measuring cytotoxic factor/tumor
necrosis factor from human monocytes. $f$ Immunol necrosis factor from human

27 Hanssen MB, Nielsen SE, Berg K. Re-examination and further development of a precise and rapid dye method for measuring cell growth/cell kill. f Immunol Methods 1989; 119: 203-10.

28 Selkurt EE. Measurement of renal blood flow. Meth Med Res 1948; 1: 191-9.

29 Dejong CHC, Kampman MT, Deutz NEP, Soeters PB. Altered glutamine metabolism in rat portal drained viscera and hindquarter during hyperammonemia. Gastroand hindquarter during

enterology 1992; 102: $936-48$.
30 Rose BD. Clinical physiology of acid-base and electrolyte disorders. Tokyo: McGraw-Hill Kogakusha, 1977: 548 .

31 Norusis MJ, ed. SPSS/PC+ V3.1 Base manual for the IBM PC/XT/AT and PS/2. SPSS Inc, Chicago, USA.

32 Wait RB, Kahng KU. Renal failure complicating obstructive jaundice. Am $\mathcal{F}$ Surg 1989; 157: 256-63.

33 Pitt HA, Cameron JL, Postier RG, Gadacz TR. Factors affecting mortality in biliary tract surgery. Am $\mathcal{f}$ Surg 1981; 141: 66-72.

34 Hishida A, Honda N, Sudo M, Nagase M. Mechanisms of altered renal perfusion in the early stage of obstructive jaundice. Kidney Int 1980; 1: 223-30.

35 Maessen JG, Greve JW, Buurman WA. Increased sensitivity to endotoxemia by tissue necrosis. Surgery 1991; 109: 154-9.

36 Froon AHM, Bemelmans MHA, Greve JW, van der Linden CJ, Buurman WA. Increased levels of soluble tumor necrosis factor receptors in sepsis syndrome: correlation with plasma creatinine. Crit Care Med 1994; 22: 803-9.

37 Beutler B, Cerami A. Cachectin: more than a tumor necrosis factor. N Engl f Med 1987; 316: 379-85.

8 Bemelmans MHA, Gouma DJ, Buurman WA. Tissue distribution and clearance of soluble murine TNF receptors in mice. Cytokine 1994; 6: 609-15.

39 Better OS, Massry SG. Effect of chronic bile duct obstruction on renal handling of salt and water. $\mathcal{F}$ Clin Invest 1975; 51: 402-11.

40 Clements WDB, Halliday MI, McCaigue MD, Barclay RG, Rowlands BJ. Effects of extrahepatic obstructive jaundice on Kupffer cell clearance capacity. Arch Surg 1993; 128: on Kupffer

41 Tanaka N, Ryden S, Bergqvist L, Christensen P, Bengmark $S$. Reticuloendothelial function in rats with obstructive jaundice. Br F Surg 1985; 72: 946-9.

42 Holman JM, Rikkers LF. Biliary obstruction and host defense failure. F Surg Res 1982; 32: 208-13.

43 Dixon JM, Armstrong CP, Duffy SW, Davies GC. Factors affecting morbidity and mortality in biliary tract surgery. Gut 1983; 24: 845-52.

4 Hamilton G, Hofbauer S, Hamilton B. Endotoxin, TNFalpha, interleukin- 6 and parameters of the cellular immune system in patients with intraabdominal sepsis. Scand $\mathcal{F}$ Infect Dis 1992; 24: 361-8.

45 Brockhaus M, Bar-Khayim Y, Gurwicz S, Frensdorff A, Haran N. Plasma tumor necrosis factor soluble receptor in chronic renal failure. Kidney Int 1992; 42: 663-7. 